\title{
Nursery fertilization affected field performance and nutrient resorption of Populus tomentosa Carr. ploidy levels
}

\author{
Miaomiao Wang ${ }^{(1-2)}$, \\ Guolei Li ${ }^{(1-2)}$, \\ Yong Liu ${ }^{(1-2)}$
}

\begin{abstract}
Nutrient resorption (NuR) is an important nutrient conservative strategy but little information is available about the effect of nursery fertilization on NuR in the field. In this study, diploid and triploid one-year-old plants of Populus tomentosa Carr. were fertilized with $9 \mathrm{~g} \mathrm{~N}$ per plant, and non-fertilized plants as control. Initial functional attributes, i.e., height, diameter, stem mass, mineral nutrients and non-structural carbohydrate (NSC) levels of each tissue, were measured before planting. Field performance (survival, total height, diameter, stem volume and their growth, leaf nutrient status, and NuR) were measured in the field. Compared to control, $9 \mathrm{~g} \mathrm{~N}$ per plant was benefit for plant growth, mineral nutrients and NSC accumulation of diploids, but declined plant size of triploids before planting. While in the field, fertilization effect on plant size was inversed for each ploidy level. Nursery fertilization increased nitrogen resorption efficiency (NRE) of triploids and decreased phosphorus resorption efficiency (PRE) of both ploidy levels. Initial plant size were the most effective parameters predicting field performance and NuR. Furthermore, NRE was multi-elements controlled as indicated by the correlation of $N$ and $P$ in green and senesced leaves, while PRE was only positively correlated with $P$ in green leaves. However, there was no relationship between field growth and NuR. This study deepened our understanding of NuR from the perspective of artificial managements, for instance nursery fertilization.
\end{abstract}

Keywords: Nursery Fertilization, Nutrient Resorption, Leaf Nutrient Status, Plant Growth, Initial Functional Attributes, Ploidy Levels

\begin{abstract}
Introduction
Nutrient resorption (NuR) from senesced leaves to living tissues is an essential nutrient conservation strategy to diminish nutrient dilution from litter decomposition and alleviate the dependence upon soil fertility, and it is generally characterized as nutrient resorption efficiency (NuRE - Aerts 1996, Vergutz et al. 2012, Brant \& Chen 2015). Globally, $62.1 \%$ nitrogen $(\mathrm{N})$ and $64.9 \%$ phosphorus $(P)$ are resorbed in terrestrial plants (Vergutz et al. 2012), and contrib-
\end{abstract}

(1) Key Laboratory for Silviculture and Conservation, Ministry of Education, Beijing Forestry University, Beijing 100083 (China); (2) National Innovation Alliance of Valuable Deciduous Tree Industry, Beijing Forestry University, Beijing 100083 (China)

\section{@ Guolei Li (glli226@163.com)}

Received: Jun 24, 2021 - Accepted: Nov 17, 2021

Citation: Wang M, Li G, Liu Y (2022). Nursery fertilization affected field performance and nutrient resorption of Populus tomentosa Carr. ploidy levels. iForest 15: 16-23. - doi: 10.3832/ifor3912-014 [online 2022-01-24]

Communicated by: Gianfranco Minotta uted to $31 \%$ and $40 \%$ of plant demands in $\mathrm{N}$ and $P$, respectively (Cleveland et al. 2013). Numerous studies have addressed the factors affecting NuR (Yuan \& Chen 2009, Vergutz et al. 2012, Brant \& Chen 2015, Yuan \& Chen 2015), indicating leaf nutrient status as one of the most direct impact factor (Wright \& Westoby 2003, Kobe et al. 2005). Kobe et al. (2005) reported a negative relationship between nutrient status (in green and senesced leaves) and NuRE by analyzing 92 publications with 297 perennial species of different life-forms. Vergutz et al. (2012) also confirmed the relationship through a global meta-analysis of 86 studies with $\sim 1000$ data points with different plant types. However, some studies reported that NuR was positive or neutral related with leaf nutrient status (Aerts 1996, Yan et al. 2016, Sohrt et al. 2018). The relationship between leaf nutrient status and NuR still need to be examined with specific species or genotypes.

Leaf $\mathrm{N}$ concentration (based on mass) also correlates with plant growth. For instance, high leaf $\mathrm{N}$ concentration generally combines with great photosynthesis as chlorophylls and photosynthetic enzymes are enriched in $\mathrm{N}$ (Masclaux-Daubresse et al. 2010), and consequently, more assimilated $C$ is allocated to growth (Reich et al. 1997, Reich 2014). On the other hand, growth exerts a feedback regulation on leaf $\mathrm{N}$ status through modifying nutrient demands (Lambers et al. 2008, MasclauxDaubresse et al. 2010), which might further affect NuR. Nonetheless, limited attention has been given to the links between NuR and growth; some studies illustrated a positive relationship between growth and NuR (Crane \& Banks 1992, Nambiar \& Fife 1991, Zhang et al. 2015). Fortier et al. (2017) also showed that hybrid poplar with the most productive clones were more proficient in NuR. Whereas, Pasche et al. (2002) reported that $\mathrm{N}$ retranslocation from mature leaves do not constitute a net source supporting shoot growth of Rhododendron ferrugineum L. (Ericaceae). Salehi et al. (2013) found that Populus deltoides Marsh. cv. "Harvard" showed the largest morphological traits with the lowest NuRE.

For newly transplanted seedlings, the leaf nutrient status and growth also closely linked to initial functional attributes modified by nursery fertilization (Grossnickle 2012, Li et al. 2014, Oliet et al. 2013, VillarSalvador et al. 2013). Villar-Salvador et al. (2004) showed that high N fertilization improved Quercus ilex L. early establishment and growth in the field. Oliet et al. (2009) highlighted that seedling size advantages due to nursery fertilization in Pinus halepensis Mill. persisted 7 years after out-plantation. Additionally, the largest and nutrient-rich seedlings also showed the highest survival rate after 7 years. Fu et al. (2017) reported that Pinus tabulaeformis Carr. fer- 
Tab. 1 - Soil nutrient status at the nursery and in the field.

\begin{tabular}{lcccc}
\hline Soil layer & $\begin{array}{c}\text { Depth } \\
(\mathbf{c m})\end{array}$ & $\begin{array}{c}\mathbf{N} \\
\left(\mathbf{m g ~ k g}^{-1}\right)\end{array}$ & $\begin{array}{c}\mathbf{P} \\
\left(\mathbf{m g ~ k g}^{-1}\right)\end{array}$ & $\begin{array}{c}\mathbf{K} \\
\left(\mathbf{g ~ k g}^{-1}\right)\end{array}$ \\
\hline Nursery & $0-30$ & 363.5 & 714.0 & 4.0 \\
\hline Field & $0-30$ & 446.8 & 280.1 & 8.3 \\
& $30-60$ & 287.3 & 195.1 & 7.3 \\
\hline
\end{tabular}

tilized in the nursery with $80 \mathrm{mg} \mathrm{N}$ seedling-1 had great biomass, non-structural carbohydrates (NSC) and mineral nutrient status, as well as excellent field performance. However, to our best knowledge, there was no information about the effect of nursery fertilization on NuR in the field, and the relations between NuR and leaf nutrient status and/or growth at field influenced by nursery fertilization. Furthermore, some studies reported that the initial seedling size was the trait most correlated with field performance (Oliet et al. 2009, Villar-Salvador et al. 2013), while others showed that nursery fertilization affects field performance through impacting nutrient storage before planting (Villar-Salvador et al. 2004, Heredia-Guerrero et al. 2014, Li et al. 2014). It is warrant to investigate the effect of nursery fertilization on NuR and the relationship between NuR and field performance (i.e., leaf nutrient status and growth), as well as the initial functional attributes mostly correlated with field performance and NuR.

Polyploidization is an effective way to change morphological and physiological traits through directly increasing cell and organ size (Sattler et al. 2016, Van De Peer et al. 2017). Many previous studies have demonstrated the enhancing effects of polyploidization on growth (Zhu 1995, Zhang et al. 2013, Zhao et al. 2015, Liao et al. 2016). Chinese white poplar (Populus tomentosa (arr.) is a deciduous broadleaf tree native to northern China, which is extensively used in afforestation for ecological purposes and for timber and pulp production (Zhu 2006, Dong et al. 2011). Triploid $P$. tomentosa has been widely used thanks to its superior growth rate and wood properties in comparison to natural diploids (Zhu 2006, Zhang et al. 2013). However, scarce studies focused on NuR variation among ploidy levels. In this study, we used Chinese white poplar in two ploidy levels to investigate: (i) the effect of nursery fertilization on initial functional attributes, field performance and NuR; (ii) the relationships between NuR and leaf nutrient status and growth in the field; and (iii) the most effective initial functional attributes correlated with field performance and NuR.

\section{Materials and methods}

\section{Study site condition}

The study was conducted in State-owned nursery of Chinese white poplar at Guanx- ian County, Shandong Province $\left(36^{\circ} 30^{\prime} \mathrm{N}\right.$, $115^{\circ} 22^{\prime} \mathrm{E}$; elevation: $37 \mathrm{~m}$ a.s.l.). Climate is a semi-arid, temperate continental monsoon with an average annual temperature of $12.8-13.3^{\circ} \mathrm{C}$, while average annual precipitation was $549-600 \mathrm{~mm}$. Soil belongs to sandy loam with a pH of 7.8 and its nutrient status is reported in Tab. 1 . Soil samples were collected and measured at different depths corresponding to the distribution of plant roots (Zheng et al. 2009).

\section{Nursery experimental design}

Two ploidy levels of Chinese white poplar (Populus tomentosa Carr.) were selected: diploid "Lumao 50" (P. tomentosa) and triploid "Beilinxiongzhu1" $[(P$. alba $\times P$. glandulosa $) \times(P$. tomentosa $\times P$. bolleana $)]$. On March 16, 2017, one-year-old healthy cuttings of uniform size (diploid: $14.4 \pm 0.06 \mathrm{~cm}$ in length, $10.50 \pm 0.55 \mathrm{~mm}$ in diameter, triploid: $14.7 \pm 0.13 \mathrm{~cm}$ in length, $13.02 \pm 0.75$ $\mathrm{mm}$ in diameter, $\mathrm{n}=30$ ) were obtained and dipped in 300 ppm a-Naphthaleneacetic acid for $3 \mathrm{~s}$ to promote rooting, and then planted in plastic pots of $1500 \mathrm{~mL}$ with a depth of $20 \mathrm{~cm}$ filled with peat ("Xinyuan", Yinong nursery substrates Co., LTD, ShanThere were 1000 plants per ploidy level and 2000 plants totally. All plants were irrigated as needed. On May 15, 2017, plants were moved outdoors for acclimation and transplanted two weeks later (May 29, 2017) to an open nursery. At that moment the size of plants were $51.1 \pm 1.25 \mathrm{~cm}$ in height and $5.76 \pm 0.11 \mathrm{~mm}$ in diameter for diploids, as well as $41.9 \pm 0.88 \mathrm{~cm}$ in height and $4.49 \pm 0.19 \mathrm{~mm}$ in diameter for triploids $(n=16)$.

Nursery fertilization was used with two levels: non-fertilized plants as control and 9 g $N$ per plant as treatment ( $C a o$ et al. 2004). The fertilizer was applied twice by conventional methods, as $3 \mathrm{~g} \mathrm{~N}$ per plant on June 7 ("Huachang" compound fertilizer, Huachang Chemical Co., Jiangsu, China, $\left.18 \mathrm{~N}+18 \mathrm{P}_{2} \mathrm{O}_{5}+\mathrm{TE}\right)$ and $6 \mathrm{~g} \mathrm{~N}$ per plant on July 7 (urea, Hengsheng Chemical Co., Jiangsu, China, $\mathrm{N} \geq 46.0 \%$ ). Fertilizer was placed in holes (both sides, $15 \mathrm{~cm}$ away from the plant, $10 \mathrm{~cm}$ in depth). Irrigation was performed once a week. A completely randomized block experiment was set involving two ploidy levels with two fertilization levels, resulting in four treatments that had four blocks as four replicates. Each replicate had 100 plants (10 rows and 10 lines, $0.3 \times 1 \mathrm{~m}$ space per plant), totalling 1600 plants. dong, China) and left in a greenhouse.

\section{Field experimental design}

On March 31, 2018, one-year-old plants were transplanted to afforestation. The experimental design in the field was completely randomized with four treatments and four replicates. Each replicate with 15 plants were planted in five rows and three lines, resulting in 240 plants in total. Plants were planted in mechanically dug planting hole (diameter: $0.5 \mathrm{~m}$; depth: $0.3 \mathrm{~m}$ ) with 3 $\times 3 \mathrm{~m}$ spacing. Irrigation and weeding were performed manually three times during the growing season.

\section{Plant sampling and chemical analysis}

\section{Measurements of initial functional} attributes

On November 23, 2017, five plants per replicate (20 plants per treatment, 80 plants totally) were randomly sampled to determine height, diameter, stem mass, mineral nutrients and non-structural carbohydrates (NSC) levels as initial functional attributes. Root systems were washed to remove the growing medium and excised from the stem. Each plant part was ovendried at $65^{\circ} \mathrm{C}$ until steady weight and stem mass was determined. The stems and roots were pooled separately for the five plants of each replicate, ground and sieved through a $0.25-\mathrm{mm}$ mesh. Approximately $0.2 \mathrm{~g}$ of each subsample was wet-digested in a sulphuric acid-hydrogen peroxide mixture using a block digester, followed by mineral nutrient analysis (Lowther 1980). Nitrogen was determined using standard Kjeldahl digestion with water distillation on a distillation unit (UDK-152 ${ }^{\circledR}$, VELP Scientifica, Italy). Phosphorus (P) was determined using the molybdenum blue method (Allen 1974) with a UV-visible spectrophotometer (Agilent $8453^{\circledast}$, Waldbronn, Germany). Potassium (K) was determined using atomic emission spectroscopy (SpectrAA $220^{\oplus}$ Atomic Absorption Spectrometer, Varian Inc.,Washington, DC, USA).

Approximately $0.1 \mathrm{~g}$ of subsamples was extracted with $80 \%$ ethanol at $80^{\circ} \mathrm{C}$ for carbohydrate analysis (Wang \& Huang 2015). Concentrations of starch and soluble sugar were determined, respectively, using amylase hydrolysis or anthrone colorimetry. Final measurements were taken with a UVvisible spectrophotometer. Total NSC concentration of each tissue was soluble sugar plus starch concentration.

\section{Measurements of field performance and NuR}

Green and senesced leaves were collected from five plants of each replicate. At growth peak (August 20, 2018), forty leaves were collected from middle southern position of each replicate. Senesced leaves were collected when dry and yellow (November 23, 2018). All leaves were ovendried at $65{ }^{\circ} \mathrm{C}$ for $48 \mathrm{~h}$, ground and sieved through a $0.25-\mathrm{mm}$ mesh. Leaf $\mathrm{N}$ and $\mathrm{P}$ concentrations were measured and then, nutrient resorption efficiency (NuRE, \%) 

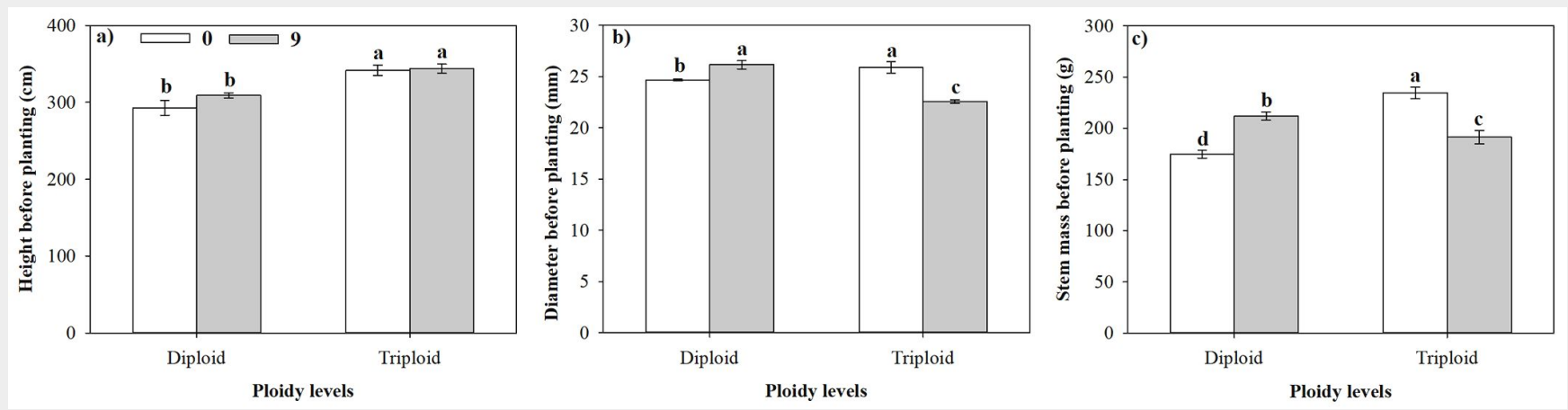

Fig. 1 - Effects of ploidy levels and fertilization on height (a), diameter (b) and stem mass (c) of one-year-old Populus tomentosa Carr. plants before field planting. Bars marked with different letters differ significantly in each variable (mean \pm SE, Fisher LSD test, $\alpha=$ $0.05, n=4)$.

was calculated as equation (eqn. 1):

$$
N u R E=\frac{\left(N u_{\text {gre }}-N u_{\text {sen }}\right)}{N u_{\text {gre }}} \cdot M L C F \cdot 100
$$

where $\mathrm{Nu}_{\text {gre }}$ and $\mathrm{Nu}_{\text {sen }}$ are nutrient concentration on mass basis in green and senesced leaves (i.e., $\mathrm{N}_{\text {gre }}, \mathrm{N}_{\text {sen }}, \mathrm{P}_{\text {gre }}$ and $\left.P_{\text {sen }}\right)$, and mass loss correction factor (MLCF) is the ratio of the dry mass of senesced leaves and green leaves; here we used 0.784 (Vergutz et al. 2012).

On November 23, at the end of growing season in the field, the survived plants were counted. Plant height and diameter were measured immediately after transplanting $\left(T_{0}\right)$ and the end of the growing season $\left(T_{1}\right)$ and the net growth was calculated as the differences between $T_{1}$ and $T_{0}$. Stem volume $\left(\mathrm{SV}, \mathrm{cm}^{3}\right)$ growth was also calculated as the differences between $T_{1}$ and $\mathrm{T}_{0}$ (eqn. 2):

$$
S V=\frac{1}{3} \cdot 3.1416 \cdot\left(\frac{D}{2}\right)^{2} \cdot H
$$

\section{Statistical analysis}

The effect of ploidy levels and fertilization and their interaction on initial functional attributes (height, diameter, stem mass, mineral nutrients and NSC levels), field performance (survival, total height, diameter and stem volume, growth of height, diameter and stem volume, as well as leaf nutrient status), as well as NuRE were assessed using two-way ANOVA; for initial functional attributes, block served as a main factor. When ANOVA assumptions were not met, data were transformed. When ANOVA results showed a significant effect, a Fisher LSD test was carried out for multiple comparisons among treatments $(\alpha=0.05)$. A generalized nonlinear model for binomial distribution and a logit link function were carried out to analyze the effects of ploidy levels and fertilization regime on survival. Statistical analyses were performed using SPSS $^{\circledast} 19.0$ (IBM, Chicago, IL, USA). Graphs and the linear regression among initial functional attributes, leaf nutrient status, growth, and NuR were obtained using SigmaPlot $^{\circledast}$ v. 12.5 (Systat Software, San José, CA, USA).

\section{Results}

Functional attributes before planting

\section{Plant size}

Regardless of fertilization, plant height of diploids was lower than that of triploids (ploidy levels and fertilization interaction: $F=0.99, p=0.346-$ Fig. $1 A$ ). There was an interactive effect between ploidy levels and fertilization on diameter $(F=64.3, p<0.001)$ and stem mass ( $F=69.1, p<0.001$ - Fig. $1 B$, Fig. 1C). Compared to controls, fertilization significantly increased diameter and stem mass of diploid plants by $6.0 \%$ and $21.2 \%$, respectively, but decreased diameter and stem mass of triploid plants by $12.9 \%$ and $18.4 \%$, respectively. Consequently, in comparison to triploids, diameter and stem mass of diploids were inferior to no fertilized plants, but superior to plants treated with $9 \mathrm{~g}$ of $\mathrm{N}$.

\section{Mineral nutrients}

Ploidy levels and fertilization affected stem nutrient concentration independently (ploidy levels and fertilization interaction, $\mathrm{F}=3.28, \quad p=0.104$ for $\mathrm{N}$ concentration; $\mathrm{F}=$ 2.03, $p=0.188$ for $P$ concentration; $F=1.35$, $p=0.275$ for $K$ concentration). Compared to control plants, fertilization significantly decreased stem $\mathrm{N}$ concentration by $20.2 \%$ in triploid plants, but significantly increased stem $\mathrm{P}$ and $\mathrm{K}$ concentration by $38.5 \%$ and $39.4 \%$ in diploid plants, respectively (Fig. $2 A-C)$. Meanwhile, stem nutrient concentrations of diploids were higher than triploids in all fertilization treatments.

Ploidy levels and fertilization significantly interactive affected only root $\mathrm{N}$ concentration ( $F=110, p<0.001$, Fig. 2D). In comparison to control plants, fertilization significantly increased root $\mathrm{N}$ concentration by $13.3 \%$ in diploid plants, but no significant effect was detected on triploids. Root $P$

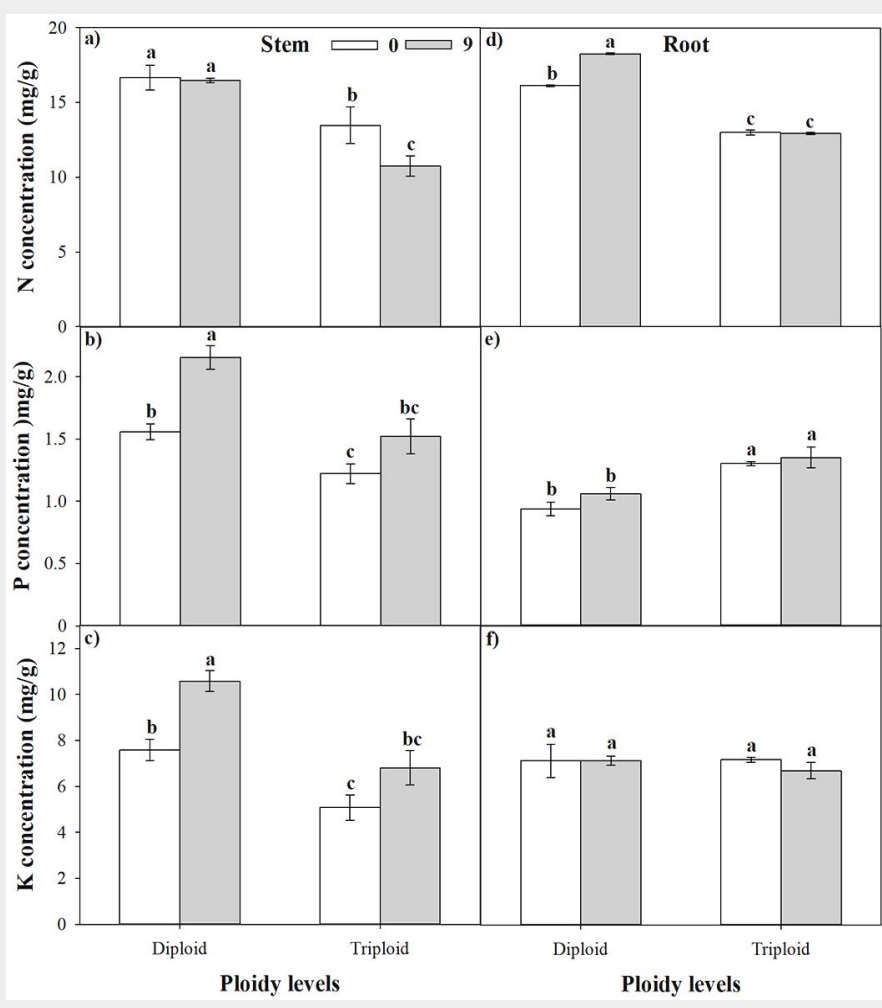

Fig. 2 - Effects of ploidy levels and fertilization on stem $\mathrm{N}(\mathrm{a}), \mathrm{P}(\mathrm{b})$, $\mathrm{K}$ (c) concentration and root $\mathrm{N}$ (d), P (e), K (f) concentration of one-year-old Populus tomentosa Carr. plants before outplanting. Bars marked with different letters differ significantly in each variable (mean \pm $\mathrm{SE}$, Fisher LSD test, $\alpha=0.05, \mathrm{n}=$ 4). 
Tab. 2 - Mean \pm SE, F and $p$ values of stem and root NSC levels with fertilization in diploid and triploid one-year-old Populus tomentosa Carr. plants before field planting (Fisher LSD test, $\alpha=0.05, \mathrm{n}=4$ ).

\begin{tabular}{|c|c|c|c|c|c|c|c|}
\hline \multirow{2}{*}{ Stats } & & \multicolumn{3}{|l|}{ Stem $\left(\mathrm{mg} \mathrm{g}^{-1}\right)$} & \multicolumn{3}{|l|}{ Root $\left(\mathrm{mg} \mathrm{g}^{-1}\right)$} \\
\hline & & Soluble sugar & Starch & NSC & Soluble sugar & Starch & NSC \\
\hline \multirow{4}{*}{ 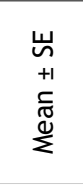 } & Diploid-0 & $21.2 \pm 1.38^{a}$ & $15.6 \pm 1.02^{b}$ & $36.8 \pm 2.01^{b}$ & $34.3 \pm 1.94^{b}$ & $22.7 \pm 1.14 \mathrm{ab}$ & $57.0 \pm 2.44^{b c}$ \\
\hline & Diploid-9 & $22.4 \pm 0.48^{a}$ & $22.7 \pm 1.07^{a}$ & $45.2 \pm 1.35^{a}$ & $31.2 \pm 0.76^{b}$ & $22.1 \pm 0.97^{\mathrm{ab}}$ & $53.3 \pm 1.51^{c}$ \\
\hline & Triploid-0 & $23.1 \pm 1.63^{a}$ & $17.0 \pm 0.85^{b}$ & $40.1 \pm 2.45^{\mathrm{ab}}$ & $40.3 \pm 1.19^{a}$ & $25.1 \pm 1.46^{a}$ & $65.4 \pm 1.85^{\mathrm{a}}$ \\
\hline & Triploid-9 & $22.4 \pm 1.10^{a}$ & $17.7 \pm 0.48^{b}$ & $40.1 \pm 1.55^{\mathrm{ab}}$ & $39.2 \pm 1.04^{a}$ & $20.8 \pm 1.43^{b}$ & $60.0 \pm 1.56^{a b}$ \\
\hline \multirow{3}{*}{ 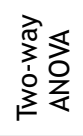 } & Ploidy levels $(P)$ & $\mathrm{F}=0.74, p=0.412$ & $\mathrm{~F}=3.38, p=0.099$ & $\mathrm{~F}=0.18, p=0.682$ & $\mathrm{~F}=24.6, p=0.001$ & $\mathrm{~F}=0.37, p=0.558$ & $\mathrm{~F}=19.9, p=0.002$ \\
\hline & Fertilization $(\mathrm{F})$ & $\mathrm{F}=0.07, p=0.803$ & $\mathrm{~F}=15.6, p=0.003$ & $\mathrm{~F}=4.31, p=0.068$ & $\mathrm{~F}=2.17, p=0.175$ & $\mathrm{~F}=7.27, p=0.025$ & $\mathrm{~F}=7.17, p=0.025$ \\
\hline & $\mathrm{P} \times \mathrm{F}$ & $\mathrm{F}=0.78, p=0.4$ & $\mathrm{~F}=10.6, p=0.01$ & $\mathrm{~F}=4.33, p=0.067$ & $\mathrm{~F}=0.50, p=0.499$ & $\mathrm{~F}=4.19, p=0.071$ & $\mathrm{~F}=0.26, p=0.623$ \\
\hline
\end{tabular}
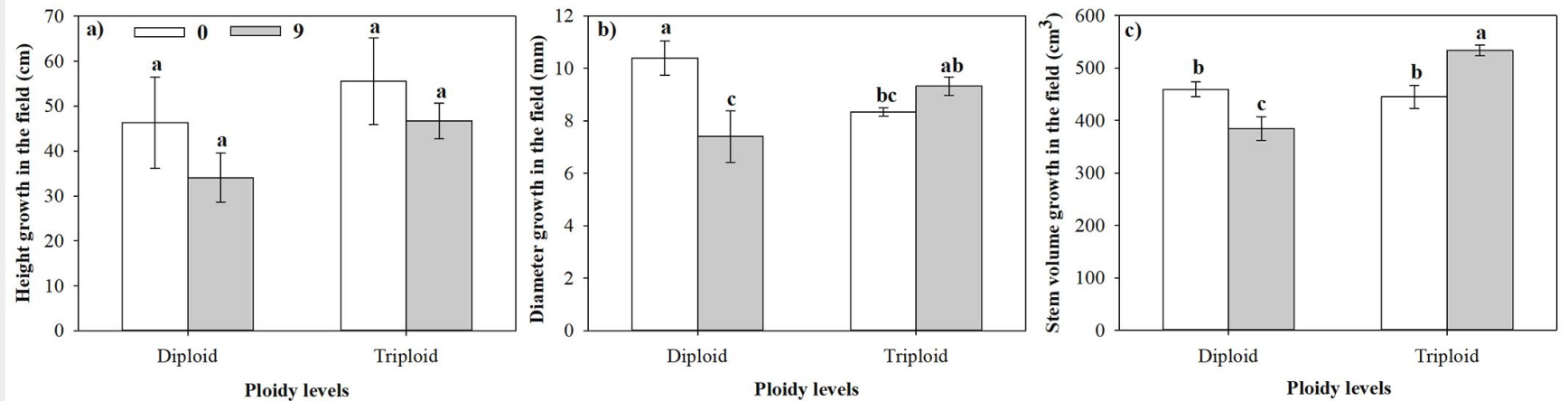

Fig. 3 - Effects of ploidy levels and fertilization on height (a), diameter (b) and stem volume growth (c) of one-year-old Populus tomentosa Carr. plants grown in the field. Different letters in each variable indicate significant differences between means (mean \pm SE, Fisher LSD test, $\alpha=0.05, n=4)$.

and $\mathrm{K}$ concentration were unaffected by plants was lower than triploids at each ferfertilization, but $P$ concentration of diploid tilization treatment (ploidy levels and fertil-

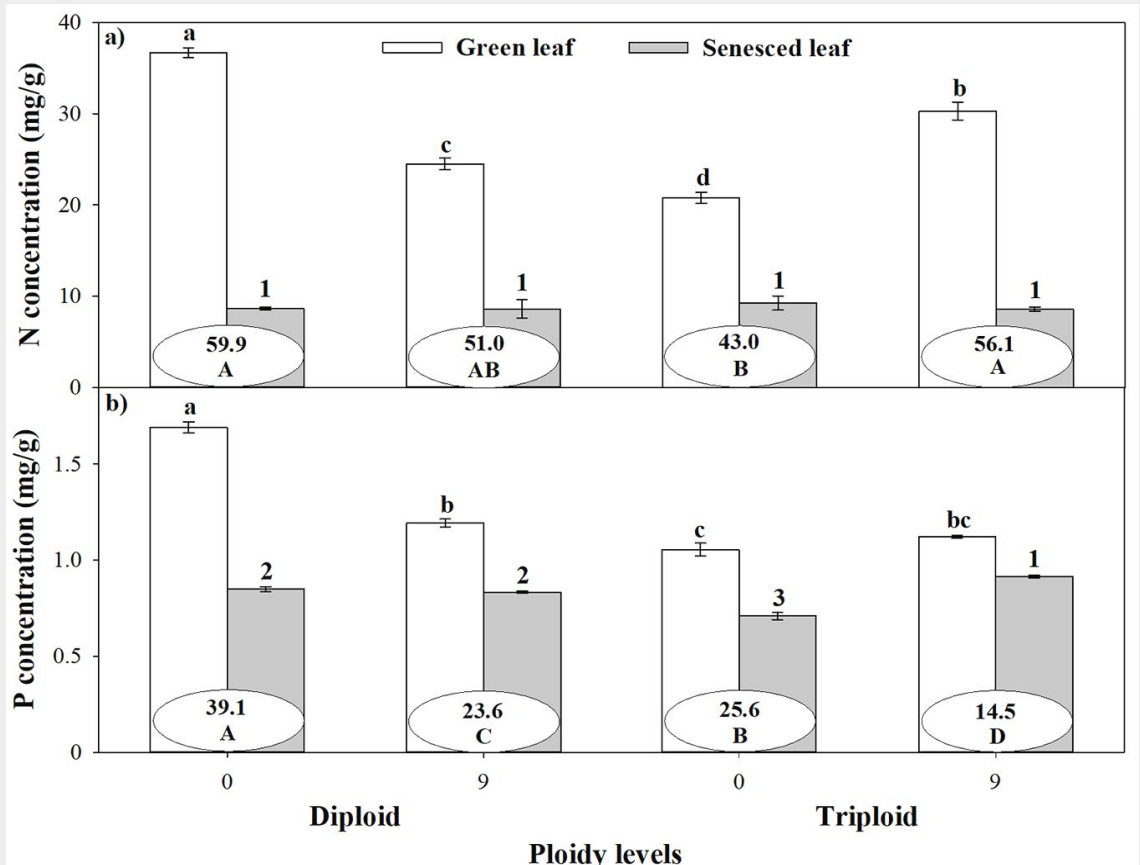

Fig. 4 - Effects of ploidy levels and fertilization on $N(a)$ and $P(b)$ concentrations of green and senesced leaves, as well as NRE (a) and PRE (b) (in oval) of one-year-old Populus tomentosa Carr. plants grown in the field. Bars marked with different lowercase letters (or numbers) indicated significantly difference of green (or senesced) leaf nutrient concentration. Different capital letters in oval indicated significantly difference of nutrient resorption efficiency (mean \pm SE, Fisher LSD test, $\alpha=0.05, n=4$ ). ization interaction, $F=0.88, p=0.372$ for $P$ concentration; $\mathrm{F}=0.38, p=0.552$ for $\mathrm{K}$ concentration, Fig. 2E-F).

\section{Non-structural carbohydrate levels}

Compared to control, fertilization with 9 g N per plant significantly increased stem NSC concentration by $22.8 \%$ in diploids, but no significant effect was detected on triploids (Tab. 2). Nonetheless, there was no significant difference in stem NSC concentration between diploid and triploid plants (Tab. 2). The increase in stem NSC concentration observed in diploid plants was mainly attributed to the increase in starch concentration (45.6\%), as indicated by the significanct combined effect between ploidy levels and fertilization (Tab. 2). However, there was no significant effect on stem soluble sugar concentration (Tab. 2).

Root NSC concentration was affected by ploidy levels and fertilization independently (Tab. 2). In all fertilization treatments, diploid plants had lower soluble sugar and NSC concentration than triploids. Compared to control plants, triploid plants fertilized with $9 \mathrm{~g} \mathrm{~N}$ showed a significant decrease $(-17.2 \%)$ in starch concentration.

Field performance and nutrient resorption

\section{Plant growth and survival rate}

At the end of growing season in the field, ploidy levels and fertilization showed a sig- 
nificant interactive effect on plant size, except for height (Tab. S1 in Supplementary material). For diploids, fertilization significantly increased total height $(+8.50 \%)$ and decreased total diameter of plants $(-6.48 \%)$ compared to controls. Therefore, no significant differences in total stem volume were found between fertilization treatments. For triploid plants, total height, diameter and stem volume were increased by $4.29 \%, 7.81 \%$ and $21.0 \%$, respectively, in response to fertilization. Consequently, total diameter and stem volume of triploids were higher than diploids fertilized with 9 $\mathrm{g} \mathrm{N}$ per plant. Furthermore, total height of triploid plants was higher than that of diploids at each fertilization treatment.

Ploidy levels and fertilization interaction had no significant effect on height growth $(\mathrm{F}=0.05, \quad p=0.833$, Fig. $3 \mathrm{~A})$ or survival $\left(\chi^{2}=0.182, p=0.669\right)$, but their combined effect was significant on diameter $(F=13.4$, $p=0.004)$ and stem volume growth $(F=$ 20.6, $p=0.001$ - Fig. 3B-C). For diploid plants, fertilization significantly decreased diameter growth by $28.8 \%$ and, consequently, stem volume growth reduced by $16.3 \%$, as compared to control plants. For triploids, the significant increase $(+19.9 \%)$ of stem volume growth in fertilized plants was mainly related to the marginally increase of diameter growth in comparison to control plants.

\section{Leaf nutrient concentration and nutrient resorption efficiency}

The interaction between ploidy levels and fertilization had a significant effect on leaf nutrient concentrations, including $\mathrm{N}_{\text {gre }}, \mathrm{P}_{\text {gre }}$ and $P_{\text {sen }}(F=198, p<0.001 ; F=125, p<0.001$; $\mathrm{F}=66.7, p<0.001$ for $\mathrm{N}_{\text {gre }}, \mathrm{P}_{\text {gre }}$ and $\mathrm{P}_{\text {sen, }}$, respectively - Fig. 4). Compared to control plants, fertilization with $9 \mathrm{~g} \mathrm{~N}$ per plant significantly decreased $\mathrm{N}_{\text {gre }}$ and $\mathrm{P}_{\text {gre }}$ in diploid plants (by $33.1 \%$ and $29.6 \%$, respectively), but significantly increased $\mathrm{N}_{\text {gre }}$ and $\mathrm{P}_{\text {sen }}$ in triploid plants (by $45.7 \%$ and $29.6 \%$, respectively). However, there was no significant effect on $\mathrm{N}_{\text {sen }}$ (ploidy-level and fertilization interaction: $\mathrm{F}=0.25, p=0.627$ ).

In comparison to control, NRE was significantly increased in fertilized triploid plants by $30.3 \%$, but no significant differences were detected in diploid plants, as indicated by the significant interaction between ploidy levels and fertilization ( $F=$ 17.0, $p=0.002-$ Fig. 4A). Furthermore, fertilization significantly decreased PRE in diploid plants by $39.5 \%$ and by $43.5 \%$ in triploid plants (ploidy levels and fertilization interaction: $\mathrm{F}=3.11, p=0.109-$ Fig. $4 \mathrm{~B}$ ). At each fertilization treatment, PRE of diploids was higher than that of triploids (Fig. 4B).

\section{Relationships among initial functional attributes, leaf nutrient status, growth and nutrient resorption efficiency}

As reported in Tab. 3, NRE was significantly and negatively correlated with stem mass and root NSC levels. Phosphorus re-

Tab. 3 - Results of the regression analysis $(y=a x+b)$ between initial functional attributes (seedling size, mineral nutrients and NSC levels) and nutrient resorption efficiency in one-year-old Populus tomentosa Carr. plants.

\begin{tabular}{|c|c|c|c|c|c|c|}
\hline$y$ & $x$ & df & $\mathbf{R}^{2}$ & $F$ & $p$ & $a$ (slope) \\
\hline \multirow{6}{*}{ 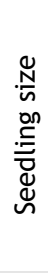 } & H-NRE & 13 & 0.2335 & 3.6553 & 0.0801 & -0.1433 \\
\hline & D-NRE & 13 & 0.1177 & 1.6009 & 0.2298 & -1.587 \\
\hline & mass-NRE & 13 & 0.5469 & 14.4831 & 0.0025 & -0.226 \\
\hline & H-PRE & 13 & 0.589 & 17.1972 & 0.0014 & -0.2569 \\
\hline & D-PRE & 13 & 0.1871 & 2.7628 & 0.1224 & 2.2598 \\
\hline & mass-PRE & 13 & 0.0602 & 0.7684 & 0.3979 & -0.0847 \\
\hline \multirow{12}{*}{ 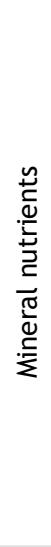 } & {$[\mathrm{N}]_{\text {stem }}-\mathrm{NRE}$} & 13 & 0.0624 & 0.7985 & 0.3891 & 0.6726 \\
\hline & {$[P]_{\text {stem }}-N R E$} & 13 & 0.0374 & 0.466 & 0.5078 & 3.8751 \\
\hline & {$[\mathrm{K}]_{\text {stem }}-\mathrm{NRE}$} & 13 & 0.0109 & 0.1327 & 0.722 & 0.3666 \\
\hline & {$[\mathrm{N}]_{\mathrm{root}}-\mathrm{NRE}$} & 13 & 0.0596 & 0.7601 & 0.4004 & 0.8507 \\
\hline & {$[P]_{\text {root }}-N R E$} & 13 & 0.0374 & 0.466 & 0.5078 & 3.8751 \\
\hline & {$[\mathrm{K}]_{\mathrm{root}}-\mathrm{NRE}$} & 13 & 0.2104 & 3.1979 & 0.099 & -5.652 \\
\hline & {$[\mathrm{N}]_{\text {stem }}-$ PRE } & 13 & 0.506 & 12.2904 & 0.0043 & 2.163 \\
\hline & {$[P]_{\text {stem }}-P R E$} & 13 & 0.0019 & 0.0229 & 0.8822 & -0.9877 \\
\hline & {$[\mathrm{K}]_{\text {stem }}-\mathrm{PRE}$} & 13 & 0.0009 & 0.011 & 0.918 & -0.1201 \\
\hline & {$[\mathrm{N}]_{\text {root }}-\mathrm{PRE}$} & 13 & 0.1878 & 2.7747 & 0.1216 & 1.7059 \\
\hline & {$[P]_{\text {root }}-P R E$} & 13 & 0.4164 & 8.5603 & 0.0127 & -29.8787 \\
\hline & {$[\mathrm{K}]_{\text {root }}-\mathrm{PRE}$} & 13 & 0.0137 & 0.1668 & 0.6902 & -1.629 \\
\hline \multirow{12}{*}{ 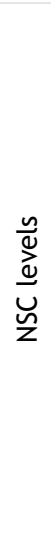 } & [Soluble sugar] $]_{\text {stem }}$-NRE & 13 & 0.0062 & 0.075 & 0.7889 & 0.2948 \\
\hline & {$[\text { Starch }]_{\text {stem }}-\mathrm{NRE}$} & 13 & 0.0068 & 0.0816 & 0.78 & -0.2217 \\
\hline & [Soluble sugar] root $-N R E$ & 13 & 0.0702 & 0.9063 & 0.3599 & -0.4583 \\
\hline & {$[\text { Starch }]_{\text {root }}-$ NRE } & 13 & 0.0062 & 0.075 & 0.7889 & 0.2948 \\
\hline & {$[\mathrm{NSC}]_{\text {stem }}-\mathrm{NRE}$} & 13 & 0.0003 & 0.0036 & 0.953 & -0.0321 \\
\hline & {$[\mathrm{NSC}]_{\mathrm{root}}-\mathrm{NRE}$} & 13 & 0.2882 & 4.8576 & 0.0478 & -0.7392 \\
\hline & [Soluble sugar] $]_{\text {stem }}$-PRE & 13 & 0.0001 & 0.0013 & 0.9715 & 0.0446 \\
\hline & {$[\text { Starch }]_{\text {stem }}-$ PRE } & 13 & 0.0904 & 1.1933 & 0.2961 & -0.916 \\
\hline & [Soluble sugar] $]_{\text {root }}$-PRE & 13 & 0.1047 & 1.403 & 0.2591 & -0.6319 \\
\hline & {$[\text { Starch }]_{\text {root }}$-PRE } & 13 & 0.0179 & 0.219 & 0.6482 & 0.4219 \\
\hline & {$[\mathrm{NSC}]_{\text {stem }}-\mathrm{PRE}$} & 13 & 0.0403 & 0.5044 & 0.4911 & -0.4191 \\
\hline & {$[\mathrm{NSC}]_{\text {root }}-\mathrm{PRE}$} & 13 & 0.0367 & 0.457 & 0.5119 & -0.2978 \\
\hline
\end{tabular}

sorption efficiency was negatively correlated with height and root $\mathrm{P}$ concentration, but positively correlated with stem $\mathrm{N}$ concentration. However, there was no significant correlation between NRE and mineral nutrients or PRE and NSC levels.

Nitrogen resorption efficiency was closely

Tab. 4 - Results of the regression analysis $(y=a x+b)$ between leaf nutrient status in the field and nutrient resorption efficiency in one-year-old Populus tomentosa Carr. plants.

\begin{tabular}{lllcccc}
\hline $\boldsymbol{y}$ & $\boldsymbol{x}$ & $\mathbf{d f}$ & $\mathbf{R}^{2}$ & $\mathbf{F}$ & $\mathbf{P}$ & $\boldsymbol{a}$ (slope) \\
\hline \multirow{3}{*}{$\mathrm{NRE}$} & {$[\mathrm{N}]_{\text {gre }}$} & 13 & 0.7021 & 28.2858 & 0.0002 & 1.064 \\
& {$[\mathrm{~N}]_{\text {sen }}$} & 13 & 0.4857 & 11.3313 & 0.0056 & -5.0637 \\
& {$[\mathrm{P}]_{\text {gre }}$} & 13 & 0.4261 & 8.9111 & 0.0114 & 20.5109 \\
& {$[\mathrm{P}]_{\text {sen }}$} & 13 & 0.6121 & 18.935 & 0.0009 & 73.2096 \\
& {$[\mathrm{~N}]_{\text {gre }}$} & 13 & 0.1315 & 1.8174 & 0.2025 & 0.52 \\
& {$[\mathrm{~N}]_{\text {sen }}$} & 13 & $1.30 \mathrm{E}-05$ & 0.0002 & 0.9902 & -0.0296 \\
& {$[\mathrm{P}]_{\text {gre }}$} & 13 & 0.6572 & 23.0056 & 0.0004 & 28.7644 \\
& {$[\mathrm{P}]_{\text {sen }}$} & 13 & 0.0949 & 1.2589 & 0.2838 & -32.5616 \\
\hline
\end{tabular}


(Tab. S2 in Supplementary material). Furthermore, leaf nutrient concentration was also related with field growth, as indicated by the positive correlation of diameter growth with $\mathrm{N}_{\text {gre }}$ and $\mathrm{P}_{\text {gre }}$ (Tab. $\mathrm{S} 3$ in Supplementary material).

\section{Discussion}

Effect of nursery fertilization on initial functional attributes and field performance

Our results showed different responses to fertilization of one-year-old plants with different ploidy levels in Populus tomentosa Carr. In response to no fertilization, triploid plants showed higher height, diameter, stem mass and root NSC levels, but lower mineral nutrient status (except for root $\mathrm{P}$ and $\mathrm{K}$ concentration) than diploid plants before planting (Fig. 1, Fig. 2, Tab. 2). However, triploid plants grown in the field kept superior performances only regarding total height (Tab. S1 in Supplementary material). Total diameter and stem volume, as well as their growth and nutrient status of green and senesced leaves for diploid plants were similar or even higher than those found in triploid plants (Fig. 3, Fig. 4, Tab. S1 in Supplementary material), implying that diploids with small size but enriched mineral nutrient status performed better than triploid plants in the field. After fertilization with $9 \mathrm{~g} \mathrm{~N}$ per plant, diploid plants increased their diameter and stem mass, as well as mineral nutrients (stem $P$ and $\mathrm{K}$, and root $\mathrm{N}$ concentration) and stem NSC levels. Contrastingly, triploids had reduced diameter and stem mass, as well as stem $\mathrm{N}$ and root starch concentrations before planting (Fig. 1, Fig. 2, Tab. 2). Consequently, diploid plants were superior in plant size and mineral nutrient status (except for root $\mathrm{P}$ and $\mathrm{K}$ concentration) but inferior in root NSC levels in comparison to triploids. In the field, fertilization of diploid plants with $9 \mathrm{~g} \mathrm{~N}$ decreased the diameter and the stem volume growth, as well as $\mathrm{N}_{\text {gre }}$ and $\mathrm{P}_{\text {gre }}$, but the opposite responses in total height and diameter led to non-difference of total stem volume between fertilization treatments. While for triploid plants, fertilization with $9 \mathrm{~g} \mathrm{~N}$ significantly enhanced diameter and stem volume growth, $\mathrm{N}_{\text {gre }}$ and $\mathrm{P}_{\text {sen, }}$ as well as total height, diameter and stem volume. Therefore, triploid plants were larger in size and growth than diploids, suggesting that the lower initial plant size in triploid plants was reversed in the filed, and root NSC levels might contribute to this variation.

Under our experimental condition, nursery fertilization affected initial functional attributes, which in turn affect field performance of poplar seedlings. At each fertilization treatment, plants with small initial size performed better in the field, suggesting that initial plant size was more correlated with field performances, and the accumulation of mineral nutrients or NSC might trigger these performances. Many studies demonstrated the importance of mineral nutrient status and/or NSC levels on field performances of seedlings (Millard \& Grelet 2010, Villar-Salvador et al. 2015, Grossnickle \& MacDonald 2018). However, in our study small-sized plants performed better in the field than large size seedlings, differing from previous studies (Cuesta et al. 2010, Oliet et al. 2009, Villar-Salvador et al. 2013). A possible explanation is based on different field conditions in our study. Grossnickle \& MacDonald (2018) concluded that small plants can grow better under stressful conditions by reducing resource consumption. In our experimental conditions, soil nutrients (especially $\mathrm{N}$ ) in the field might be $\mathrm{N}$-deficient for Chinese white poplars, and this may represent a stress for outplanted seedlings. However, as indicated by the decrease in plant size and mineral nutrients of triploids before planting, our study did not take into account genotypes-specific responses to optimal fertilization (Gan et al. 2015, Luo et al. 2013, Villar-Salvador et al. 2013). Furthermore, previous studies have demonstrated the contribution of diazotrophic endophyte consortia on decreasing fertilizer input and increasing mass accumulation in poplar (Rogers et al. 2012, Knoth et al. 2014). In our study, different diazotrophic endophyte consortia of each ploidy level, combined with different soil conditions between nursery and the field, could further explain the observed growth differences.

\section{The relationship between initial} functional attributes, leaf nutrient status, growth and nutrient resorption In our study, nursery fertilization increased NRE of triploids and decreased PRE of both ploidy levels. In all the fertilization treatments, NRE and PRE of diploid plants were higher than those of triploids except for NRE at $9 \mathrm{~g} \mathrm{~N}$ per plant. Vergutz et al. (2012) reported that mean values of NRE and PRE of temperate deciduous species were $57.6 \%$ and $54.1 \%$, respectively. Yan et al. (2018) showed that mean values of NRE and PRE in woody species were $48.4 \%$ and $53.3 \%$, respectively. Under our experimental conditions, NRE was 43.0-59.9\%, which in line with global mean values, but PRE (14.5-39.1\%) was lower. Furthermore, the observed values were much higher than other Poplar species or clones for NRE (12.09-18.93\%) but similar or lower for PRE (32.46-39.63\% - Salehi et al. 2013), suggesting that nutrient resorption is species-, clones- or even ploidy-level specific. Furthermore, the difference of environmental conditions, time of collecting leaves, plant age or measurements methods might also contribute to the observed difference (Brant \& Chen 2015).

Our results showed that NRE was positively related to $\mathrm{N}_{\text {gre }}, \mathrm{P}_{\text {gre }}$ and $\mathrm{P}_{\text {sen }}$, but negatively associated with $\mathrm{N}_{\text {sen }}$ (Tab. 4), suggesting that NRE is multi-elements controlled, while PRE was only positively related with $\mathrm{P}_{\text {gre }}$ (Tab. 4). The relationship was consistent with the findings reported by several studies (Zhou et al. 2016, Zeng et al. 2017, Ji et al. 2018), but differed from others (Aerts 1996, Kobe et al. 2005, Vergutz et al. 2012). Species-specificity, plant age, environmental conditions, time of collecting leaves or different measurement methods might underlie such contrasting evidence (Brant \& Chen 2015). Furthermore, the close relationship between diameter growth and $\mathrm{N}_{\text {gre }}$ or $\mathrm{P}_{\text {gre }}$ in the field (see Tab. S3 in Supplementary material) confirmed the positive correlation between $\mathrm{N}_{\text {gre }}$ and growth (Reich et al. 1997, Reich 2014). However, there was no relationship between field growth and NuR, consistently with previous studies (Harvey \& Van Den Driessche 1999, Pasche et al. 2002) and implying that field growth is not dependent factor for NuR. The different result with other studies (Salehi et al. 2013, Zhang et al. 2015) might be attributed to variation in plant age, experimental conditions and/or methods (Brant \& Chen 2015). Furthermore, initial functional attributes were correlated with NuR (Tab. 4, Tab. S2 in Supplementary material). Plant size was negatively related with both NRE and PRE, while mineral nutrients correlated with PRE, and NSC levels correlated with NRE, respectively. Considering previous studies reporting that initial morphological traits were mostly correlated with field performance (Oliet et al. 2009, Villar-Salvador et al. 2013), our results suggest that the initial plant size is the most important parameters impacting field performance in Chinese white poplars, also combined with NuR.

\section{Conclusion}

We investigated the effect of nursery fertilization on nutrient resorption in the field, as well as its relationship with field leaf nutrient status and growth in Chinese white poplar. Under our experimental conditions, fertilization with $9 \mathrm{~g} \mathrm{~N}$ per plant provided benefits in terms of initial plant size, mineral nutrients and NSC levels before planting, but impaired field performance of diploid plants. While for triploids, the initial lower size of plants can be reversed in the field. Nursery fertilization increased NRE of triploids and decreased PRE of both ploidy levels in the field. Along with the relationship between initial functional attributes and NuR (i.e., plant size was negatively related with both NRE and PRE), our results showed that initial plant size was the most effective parameter in predicting both field performance and NuR. Furthermore, NuR (especially NRE) closely correlates with leaf nutrient status, while no relationship with growth was found in the field. Our results fill the gap in understanding NuR in terms of artificial managements, for instance nursery fertilization. Further study are needed to optimize the fertilization regime in different field conditions and nutrient resorption with long-term monitoring. 


\section{Acknowledgements}

The study was funded by the National Key Research and Development Program of China (2016YFD0600403).

\section{Conflict of Interest}

The authors declare that they have no conflict of interest.

\section{References}

Aerts R (1996). Nutrient resorption from senescing leaves of perennials: are there general patterns? The Journal of Ecology 84 (4): 597-608. doi: $10.2307 / 2261481$

Allen S (1974). Chemical analysis of ecological materials. Blackwell Scientific, Oxford, UK, pp. 575.

Brant AN, Chen HYH (2015). Patterns and mechanisms of nutrient resorption in plants. Critical Reviews in Plant Sciences 34 (5): 471-486. - doi: 10.1080/07352689.2015.1078611

Cao B, Gong Q, Qi Q (2004). Study on effects of different fertilizer scheme on seedlings of triploid Populus tomentosa. Journal of Shandong Agricultural University (Natural Science) 35: 512-516. [in Chinese] - doi: 10.3969/j.issn.10002324.2004.04.009

Cleveland CC, Houlton BZ, Smith WK, Marklein AR, Reed SC, Parton W, Del Grosso SJ, Running SW (2013). Patterns of new versus recycled primary production in the terrestrial biosphere. Proceedings of the National Academy of Sciences USA 110 (31): 12733-12737. - doi: 10.1073/ pnas.1302768110

Crane WJB, Banks JCG (1992). Accumulation and retranslocation of foliar nitrogen in fertilised and irrigated Pinus radiata. Forest Ecology and Management 52 (1-4): 201-223. - doi: 10.1016/ 0378-1127(92)90502-Z

Cuesta B, Villar-Salvador P, Puértolas J, Jacobs DF, Rey Benayas JM (2010). Why do large, nitrogen rich seedlings better resist stressful transplanting conditions? A physiological analysis in two functionally contrasting Mediterranean forest species. Forest Ecology and Management 260: 71-78. - doi: 10.1016/j.foreco.2010.0 4.002

Dong W, Qin J, Li J, Zhao Y, Nie L, Zhang Z (2011). Interactions between soil water content and fertilizer on growth characteristics and biomass yield of Chinese white poplar (Populus tomentosa Carr.) seedlings. Soil Science and Plant Nutrition 57 (2): 303-312. - doi: 10.1080/00380768. 2010.549445

Fortier J, Truax B, Gagnon D, Lambert F (2017). Linking biomass productivity to genotype-specific nutrient cycling strategies in mature hybrid poplars planted along an environmental gradient. BioEnergy Research 10 (3): 876-890. - doi: 10.1007/s12155-017-9850-7

Fu Y, Oliet JA, Li G, Wang J (2017). Effect of controlled release fertilizer type and rate on mineral nutrients, non-structural carbohydrates, and field performance of Chinese pine container-grown seedlings. Silva Fennica 51 (2): 113. - doi: 10.14214/sf.1607

Gan H, Jiao Y, Jia J, Wang X, Li H, Shi W, Peng C, Polle A, Luo Bin Z (2015). Phosphorus and nitrogen physiology of two contrasting poplar genotypes when exposed to phosphorus and/or nitrogen starvation. Tree Physiology 36 (1): 22-38. doi: 10.1093/treephys/tpvo93

Grossnickle SC (2012). Why seedlings survive: influence of plant attributes. New Forests 43 (56): 711-738. - doi: 10.1007/s11056-012-9336-6 Grossnickle SC, MacDonald JE (2018). Why seedlings grow: influence of plant attributes. New Forests 49 (1): 1-34. - doi: 10.1007/s11056-017-96 06-4

Harvey HP, Van Den Driessche R (1999). Poplar nutrient resorption in fall or drought: influence of nutrient status and clone. Canadian Journal of Forest Research 29: 1916-1925. - doi: 10.1139/ cjfr-29-12-1916

Heredia-Guerrero N, Oliet JA, Villar-Salvador $\mathrm{P}$, Benito LF, Peñuelas JL (2014). Fertilization regime interacts with fall temperature in the nursery to determine the frost and drought tolerance of the Mediterranean oak Quercus ilex subsp. ballota. Forest Ecology and Management 331 (5): 50-59. - doi: 10.1016/j.foreco.2014. 07.022

Ji H, Wen J, Du B, Sun N, Berg B, Liu C (2018). Comparison of the nutrient resorption stoichiometry of Quercus variabilis Blume growing in two sites contrasting in soil phosphorus content. Annals of Forest Science 75 (2): 597. - doi: 10.1007/s13595-018-0727-5

Knoth JL, Kim SH, Ettl GJ, Doty SL (2014). Biological nitrogen fixation and biomass accumulation within poplar clones as a result of inoculations with diazotrophic endophyte consortia. New Phytologist 201 (2): 599-609. - doi: 10.1111/nph. 12536

Kobe RK, Lepczyk CA, lyer M (2005). Resorption efficiency decreases with increasing green leaf nutrients in a global data set. Ecology 86: 27802792. - doi: 10.1890/04-1830

Lambers H, Chapin III, Pons TL (2008). Plant physiological ecology $\left(2^{\text {nd }}\right.$ edn). Springer, New York, USA, pp. 248-249.

Li G, Zhu Y, Liu Y, Wang J, Liu J, Dumroese RK (2014). Combined effects of pre-hardening and fall fertilization on nitrogen translocation and storage in Quercus variabilis seedlings. European Journal of Forest Research 133 (6): 983992. - doi: 10.1007/s10342-014-0816-4

Liao T, Cheng S, Zhu X, Min Y, Kang X (2016). Effects of triploid status on growth, photosynthesis, and leaf area in Populus. Trees 30: 11371147. - doi: 10.1007/s00468-016-1352-2

Lowther J (1980). Use of a single sulphuric-hydrogen peroxide digest for the analysis of $\mathrm{Pi}$ nus radiata needles. Communications in Soil Science and Plant Analysis 11 (2): 175-188. - doi: 10.1080/00103628009367026

Luo J, Li H, Liu T, Polle A, Peng C, Luo Bin Z (2013). Nitrogen metabolism of two contrasting poplar species during acclimation to limiting nitrogen availability. Journal of Experimental Botany 64 (14): 4207-4224. - doi: 10.1093/jxb/ ert234

Masclaux-Daubresse C, Daniel-Vedele F, Dechorgnat J, Chardon F, Gaufichon L, Suzuki A (2010). Nitrogen uptake, assimilation and remobilization in plants: challenges for sustainable and productive agriculture. Annals of Botany 105 (7): 1141-1157. - doi: 10.1093/aob/mcq028

Millard P, Grelet GA (2010). Nitrogen storage and remobilization by trees: ecophysiological relevance in a changing world. Tree Physiology 30 (9): 1083-1095. - doi: 10.1093/treephys/tpq042
Nambiar EKS, Fife DN (1991). Nutrient retranslocation in temperate conifers. Tree Physiology 9 (1-2): 185-207. - doi: 10.1093/treephys/9.1-2.185 Oliet JA, Planelles R, Artero F, Valverde R, Jacobs DF, Segura ML (2009). Field performance of $\mathrm{Pi}$ nus halepensis planted in Mediterranean arid conditions: relative influence of seedling morphology and mineral nutrition. New Forests 37 (3): 313-331. - doi: 10.1007/s11056-008-9126-3 Oliet JA, Puértolas J, Planelles R, Jacobs DF (2013). Nutrient loading of forest tree seedlings to promote stress resistance and field performance: a Mediterranean perspective. New Forests 44 (5): 649-669. - doi: 10.1007/s11056-0139382-8

Pasche F, Pornon A, Lamaze T (2002). Do mature leaves provide a net source of nitrogen supporting shoot growth in Rhododendron ferrugineum? New Phytologist 154 (1): 99-105. - doi: 10.1046/j.1469-8137.2002.00370.x

Reich PB (2014). The world-wide "fast-slow" plant economics spectrum: a traits manifesto. Journal of Ecology 102 (2): 275-301. - doi: 10.1111/ 1365-2745.12211

Reich PB, Walters MB, Ellsworth DS (1997). From tropics to tundra: global convergence in plant functioning. Proceedings of the National Academy of Sciences USA 94 (25): 13730-13734. - doi: 10.1073/pnas.94.25.13730

Rogers A, McDonald K, Muehlbauer MF, Hoffman A, Koenig K, Newman L, Taghavi S, Van Der Lelie D (2012). Inoculation of hybrid poplar with the endophytic bacterium Enterobacter sp. 638 increases biomass but does not impact leaf level physiology. GCB Bioenergy 4 (3): 364370. - doi: 10.1111/j.1757-1707.2011.01119.x

Salehi A, Ghorbanzadeh N, Salehi M (2013). Soil nutrient status, nutrient return and retranslocation in poplar species and clones in northern Iran. iForest 6: 336-341. - doi: 10.3832/iforo976006

Sattler MC, Carvalho CR, Clarindo WR (2016). The polyploidy and its key role in plant breeding. Planta 243: 281-296. - doi: 10.1007/s00425-0152450-x

Sohrt J, Herschbach C, Weiler M (2018). Foliar Pbut not $\mathrm{N}$ resorption efficiency depends on the $\mathrm{P}$-concentration and the $\mathrm{N}$ : $\mathrm{P}$ ratio in trees of temperate forests. Trees 32 (5): 1443-1455. - doi: 10.1007/s00468-018-1725-9

Van De Peer Y, Mizrachi E, Marchal K (2017). The evolutionary significance of polyploidy. Nature Reviews Genetics 18 (7): 411-424. - doi: 10.1038/ nrg.2017.26

Vergutz L, Manzoni S, Porporato A, Novais RF, Jackson RB (2012). Global resorption efficiencies and concentrations of carbon and nutrients in leaves of terrestrial plants. Ecological Monographs 82 (2): 205-220. - doi: 10.1890/110416.1

Villar-Salvador P, Peñuelas JL, Nicolás-Peragón JL, Benito LF, Domínguez-Lerena S (2013). Is nitrogen fertilization in the nursery a suitable tool for enhancing the performance of Mediterranean oak plantations? New Forests 44 (5): 733-751. - doi: 10.1007/s11056-013-9374-8 Villar-Salvador P, Planelles R, Enríquez E, Rubira JP (2004). Nursery cultivation regimes, plant functional attributes, and field performance relationships in the Mediterranean oak Quercus ilex L. Forest Ecology and Management 196 (2- 
3): 257-266. - doi: 10.1016/j.foreco.2004.02.061 Villar-Salvador P, Uscola M, Jacobs DF (2015). The role of stored carbohydrates and nitrogen in the growth and stress tolerance of planted forest trees. New Forests 46 (5-6): 813-839. doi: 10.1007/s11056-015-9499-z

Wang X, Huang J (2015). Principles and techniques of plant physiological biochemical experiment. Higher Education Press, Beijing, China, pp. 171-186. [In Chinese]

Wright IJ, Westoby M (2003). Nutrient concentration, resorption and lifespan: leaf traits of Australian sclerophyll species. Functional Ecology 17 (1): 10-19. - doi: 10.1046/j.1365-2435.2003. 00694.x

Yan T, Lü X, Yang K, Zhu J (2016). Leaf nutrient dynamics and nutrient resorption: a comparison between larch plantations and adjacent secondary forests in Northeast China. Journal of Plant Ecology 9 (2): 165-173. - doi: 10.1093/ jpe/rtv034

Yan T, Zhu J, Yang K (2018). Leaf nitrogen and phosphorus resorption of woody species in response to climatic conditions and soil nutrients: a meta-analysis. Journal of Forestry Research 29 (4): 905-913. - doi: 10.1007/s11676-017-0519-z Yuan ZY, Chen HYH (2015). Concepts and synthesis. Ecology 96 (2): 373-380. - doi: 10.1890/140140.1

Yuan ZY, Chen HYH (2009). Global-scale patterns of nutrient resorption associated with latitude, temperature and precipitation. Global Ecology and Biogeography 18 (1): 11-18. - doi: 10.1111/j.146 6-8238.2008.00425.x

Zeng Y, Fang X, Xiang W, Deng X, Peng C (2017). Stoichiometric and nutrient resorption characteristics of dominant tree species in subtropical Chinese forests. Ecology and Evolution 7 (24): 11033-11043. - doi: 10.1002/ece3.3527

Zhang P, Wu F, Kang X (2013). Genetic control of fiber properties and growth in triploid hybrid clones of Populus tomentosa. Scandinavian Journal of Forest Research 28 (7): 621-630. doi: $10.1080 / 02827581.2013 .829868$

Zhang JL, Zhang SB, Chen YJ, Zhang YP, Poorter $L$ (2015). Nutrient resorption is associated with leaf vein density and growth performance of dipterocarp tree species. Journal of Ecology 103 (3): 541-549. - doi: 10.1111/1365-2745.12392

Zhao X, Li Y, Zheng M, Bian X, Liu M, Sun Y, Jiang J, Wang F, Li S, Cui Y, Liu G, Yang C (2015). Comparative analysis of growth and photosynthetic characteristics of (Populus simonii $\times$ P. nigra) $\times$ $(P$. nigra $\times P$. simonii) hybrid clones of different ploidides. PLoS One 10: 1-16. - doi: 10.1371/jour nal.pone.0119259

Zheng S, Gao R, Liu F (2009). Poplar cultivation. Golden Shield Publishing House, Beijing, China, pp. 92-108. [In Chinese]

Zhou L, Addo-Danso SD, Wu P, Li S, Zou X, Zhang $Y$, Ma X (2016). Leaf resorption efficiency in relation to foliar and soil nutrient concentrations and stoichiometry of Cunninghamia lanceolata with stand development in southern China.
Journal of Soils and Sediments 16 (5): 14481459. - doi: 10.1007/s11368-016-1352-2

Zhu, Z, Lin H, Kang X (1995). Studies on allotriploid breeding of Populus tomentosa B301 clones. Scientia Silvae Sinicae 31 (6): 499-505. [online] URL: http://www.linyekexue.net/CN/Y1 995/V31/16/499

Zhu Z (2006). Breeding of triploid Populus tomentosa. In: "Genetic Improvement of Populus tomentosa" (Zhu Z ed). Chinese Forestry Press, Beijing, China, pp. 155-220.

\section{Supplementary Material}

Tab. S1 - Mean \pm SE, F and $p$ values of total height, diameter and stem volume with fertilization in diploid and triploid one-year-old Populus tomentosa Carr. at the end of growing season.

Tab. S2 - F, $p$, and $\mathrm{R}^{2}$ values of linear regression $(y=a x+b)$ between field growth and nutrient resorption efficiency of one-yearold Populus tomentosa Carr.

Tab. S3 - F, p, and $\mathrm{R}^{2}$ values of linear regression $(y=a x+b)$ between field growth and leaf nutrient status of one-year-old Populus tomentosa Carr.

Link:Wang_3912@supploo1.pdf 